\title{
Chronic periodontitis in a group of patients with chronic autoimmune thyroiditis - particularities of expression
}

\author{
Parodontita cronică la un lot de pacienţi cu tiroidită cronică autoimună - \\ particularităţi de expresie \\ Răzvan Circo ${ }^{1}$, Cristina Gosu', Victoria Badea² \\ ${ }^{1}$ Circo Dentistry, Bucureşti, România \\ 2Disciplina Imunologie, Facultatea de Medicină Dentară, Universitatea „Ovidius“, Constanţa, România
}

\begin{abstract}
Objectives. The intricacy of the inflammatory / infiltrative process common to chronic autoimmune thyroid disease and periodontal disease (CP) justifies the study of the incidence and expression peculiarities of periodontal lesions encountered in patients with chronic autoimmune thyroiditis (CAT). The presence of periodontal plaque correlated with the oral hygiene index represents a proof of the microbial aggression, as a "trigger" in initiating the pathological process with a progressive evolution.

Material and method. The study included patients with CP: group 1 - associating CAT, group 2 - without thyroid disease. The periodontal status was assessed: mild, medium, aggravated. Statistically correlated variables: periodontal lesions, sex, age of patients, OHI-s, thyroid functional status (TSH), serum level of thyroid autoantibodies (ATPO / ATg) and antinuclear antibodies (ANA).

Results. A heterogeneity of the distribution of periodontal lesions in both groups was found. The preponderance of lesions with statistical significance $(p<0.001)$ predominated for study group 1 . Aggravated periodontal status: more common in group $1(p=0.043)$, was not influenced by the sex of the patients. The monofactorial linear regression finds the average interdependence between the OHI-s value and the age of the patients $(r=0.63 ; p=0.018)$ and the TSH problem $(r=0.55 ; p=0.0003)$. The multifactorial linear regression, however, attests a direct proportional relationship between OHI-s and TSH, ATPO, ATg $(r=0.56$; $p=0.001)$ and intensified with age $(r=0.78, p<0.001)$. Effect on OHI-s calculated by ANOVA test: ATPO $(\operatorname{Pr}=78.66 \% ; r=0.73 ; p=0.05) ; A \operatorname{Tg}(\operatorname{Pr}=94.06 \% ; r=0.73 ; p=0.042) ;$ both antibodies $(\operatorname{Pr}=96.28 \%$, $r=0.87 ; p=0.003)$, correlated with age $(r=0.99 ; p<0.001)$. No statistical correlation for ANA was found. Conclusions. The presence and progressive characteristics of CP in patients with CAT attests the etiopathogenic interference of the two diseases and requests an interdisciplinary therapeutic attitude.
\end{abstract}

Keywords: periodontal disease, chronic autoimmune thyroiditis, oral hygiene index

\section{REZUMAT}

Obiective. Intricarea procesului inflamator/infiltrativ comun bolii tiroidiene autoimune şi parodontitei cronice (PC) justifică studiul incidenţei şi al particularităţilor de expresie a leziunilor parodontale întâlnite la pacienţii cu tiroidită cronică autoimună (TCA).

Placa parodontală corelată cu indicele de igienă orală reprezintă un suport al agresiunii microbiene, factor trigger în iniţierea procesului patologic cu evoluţie progresivă.

Material şi metodă. Studiul a inclus pacienţi cu PC: lotul 1 - asociind TCA, lotul 2 fără afectare tiroidiană. Variabile corelate statistic: leziunile parodontale, sexul, vârsta pacienţilor, $\mathrm{OHI}-\mathrm{s}$, statusul funcţional tiroidian (TSH), nivelul seric al autoanticorpilor tiroidieni (ATPO/ATg) şi anticorpilor antinucleari (ANA).

Rezultate. S-a constatat o heterogenitate a distribuţiei leziunilor parodontale în ambele loturi. Preponderenţa leziunilor cu semnificaţie statistică ( $p<0,001$ ), totuşi, a predominat pentru lotul 1 de studiu. Statusul parodontal agravat, mai frecvent întâlnit la lotul $1(p=0,043)$, nu a fost influenţat de sexul pacienţilor. Regresia liniară monofactorială constată interdependenţa medie între valoare OHI-s şi vârsta pacienţilor $(r=0,63 ; p=0,018)$ şi valoarea TSH $(r=0,55 ; p=0,0003)$. Regresia liniară plurifactorială atestă însă o relaţie direct proporţională între OHI-s şi TSH, ATPO, ATg ( $r=0,56 ; p=0,001)$ şi intensificată cu vârsta $(r=0,78, p<0,001)$. Efectul asupra OHI-s calculat (testul ANOVA): ATPO (Pr = 78,66\%; $r=0,73 ; p=0,05)$; ATg $(\operatorname{Pr}=94,06 \% ; r=0,73 ; p=0,042)$; ambii anticorpi $(\operatorname{Pr}=96,28 \%, r=0,87 ; p=0,003)$, corelat vârstei $(r=0,99 ; p<0,001)$. Nicio corelaţie statistică pentru ANA. 
Concluzii. Prezenţa şi caracteristicile evolutive ale PC la pacienţii cu TCA atestă interferenţa etiopatogenică a celor două boli şi impune o atitudine terapeutică interdisciplinară.

Cuvinte cheie: parodontită cronică, tiroidită cronică autoimună, indice igienă orală

\author{
Abrevieri \\ PC - parodontită cronică; \\ TCA - tiroidită cronică autoimună; \\ TSH - hormon tireotrop hipofizar; \\ ATg - anticorpi antitiroglobulină; \\ ANA - anticorpi antinucleari; \\ ATPO - anticorpi antitiroidperoxidază; \\ OHI-s - indice de igienă orală simplificat
}

\section{INTRODUCERE}

Boala parodontală este o afecţiune complexă, amorsând procese inflamatorii şi autoimune, etapele evolutive fiind apreciate in funcţie de criteriile de diagnostic (1). Inflamaţia parodonţiului este precedată de gingivită. Gingivita cronică asociază degradarea colagenului, iar evoluţia ei spre boala parodontală se produce în 10-15\% dintre cazuri, în funcţie de o serie de factori de mediu, dar şi de predispoziţia genetică/individuală $(2,3)$.

Mecanismul imunologic declanşat de procesul infecţios produce alterarea adaptativă a celulelor imunitare, limfocitele $\mathrm{B}$, cu producere excesivă de interleukină 1 şi interleukină 6 , şi a activităţii macrofagelor, cu producerea de IL-1, TNF-alfa şi IL-17 (4), la care se adaugă stimularea populaţiei de oasteoclaste ce vor distruge ţesutul conectiv, cu pierderea de masă osoasă (5).

Studii imunohistochimice au precizat implicarea celulelor T în gingivită şi a celulelor B/plasmocitare în parodontita cronică (6). Aceste celule vor produce prostaglandine (PGE2) şi metaloproteinaze matriceale ce vor distruge ţesutul conectiv (7). Hormonii tiroidieni recepţionaţi de osteoblaşti joacă un rol în controlul resorbţiei osoase, acţionând asupra osteoprotegerinei (OPG), ligandul de activare a sistemului RANK (RANK-L) şi asupra factorilor reglatori ai metabolismului osos, cum ar fi IL-6 şi IL-8 (8).

Densitatea capilară crescută şi alterarea microcirculaţiei sunt observate atât în TCA, cât şi în PC şi pun problema mecanismului autoimun de afectare a substratului vascular al leziunilor tisulare realizate în cele două boli, cu implicare ANA (9).

Substratul autoimunităţii comun PC şi TCA este subliniat de asocierea frecventă a leziunilor parodontale întâlnite la pacienţi cu boli tiroidiene $(10,11,12)$. Pare posibilă o implicare a disfuncţiei tiroidiene şi a autoimunităţii în realizarea şi progresia leziunilor parodontale (13), luând în calcul procesul infecţios favorizat şi de o igienă orală defectuoasă (14).
Identificarea unor factori agravanţi în apariţia şi evoluţia leziunilor parodontale la pacienţii cu TCA, cum ar fi prezenţa autoanticorpilor tiroidieni şi a tulburărilor funcţionale tiroidiene, comparativ cu leziunile parodontale întâlnite la pacienţi numai cu PC, fără afectare tiroidiană, ar putea aduce informaţii utile ale implicării bolii autoimune tiroidiene în afectarea parodonţiului.

\section{OBIECTIVE}

Studiul şi-a propus să evidenţieze incidenţa şi particularităţile de expresie ale leziunilor parodontale întâlnite la pacienţii cu tiroidită cronică autoimună.

\section{MATERIAL ŞI METODĂ}

\section{Loturile de pacienți}

În perioada 2016-2020, au fost examinate din punct de vedere dentar un grup de pacienţi cu PC $(n=109)$ şi TCA (lotul 1) şi un grup martor cu PC $(n=91)$ fără afectare tiroidiană (lotul 2).

Structura loturilor studiate a cuprins:

- Lotul 1 - 84 femei şi 25 bărbaţi. Media de vârsta: $36 \pm 9$ ani pentru femei şi $41 \pm 7$ ani pentru bărbaţi.

- Lotul 2 - 62 femei şi 29 bărbaţi. Media de vârsta: $31 \pm 11$ ani pentru femei şi $43 \pm 12$ ani pentru bărbaţi.

\section{Criteriile de selecție a pacienților}

Criteriile de includere: PC asociată cu TCA pentru lotul 1, respectiv statusul tiroidian normal pentru lotul 2; acceptul bolnavului pentru studiu.

Criteriile de excludere: alte boli autoimune, inflamatorii, neoplazice, diabet zaharat, boli genetice malformative sau sistemice cu potenţial patogen parodontal, femei însărcinate sau în perioada de perimenopauză, fumători, parodontita agresivă, lipsa acordului pacientului pentru studiu. 
Examenul clinic dentar a fost efectuat $\mathrm{cu}$ consimţământul informat al pacienţilor. Diagnosticul de TCA a fost stabilit prin examen clinic, ecografie tiroidană şi evidenţierea prezenţei şi a nivelului seric al autoanticorpilor tiroidieni: ATPO $(<34 \mathrm{UI} / \mathrm{ml})$ şi AcTg $(<115 \mathrm{UI} / \mathrm{ml})$. Dozarea nivelului seric al hormonilor tiroidieni FT4 (0,93-1,7 ng/dl) şi TSH $(0,27-4,27 \mu \mathrm{UI} / \mathrm{ml})$ a identificat statusul funcţional - normofuncţional cu TSH normal, hipotiroidism cu valori TSH $>4,2 \mu \mathrm{UI} / \mathrm{ml}$ şi FT4 $<0,93 \mathrm{ng} / \mathrm{dl}$; hipotiroidism subclinic cu TSH $>4,2 \mu \mathrm{UI} / \mathrm{ml}$ şi FT4 în limite normale; tireotoxicoză cu TSH $<0,27 \mu \mathrm{UI} / \mathrm{ml}$ şi FT4 $>1,7 \mathrm{ng} / \mathrm{ml}$. Dozajul acestor constante a fost efectuat prin metoda electrochemiluminiscenţei (ECLIA).

\section{Criterii de evaluare a leziunilor parodontale}

Pentru evaluarea leziunilor parodontale, examenul clinic a inclus indicele de igienă orală ("simplified oral hygene index" - OHI-s - Greene \& Vermillion) apreciat în intervalul de valori 0-1,2 (scăzut), 1,3-3 (mediu), 3,1-6 (crescut). Pentru fiecare dintre pacienţi, s-au măsurat părţile bucale, linguale, meziale şi distale. Leziunile constatate au fost interpretate în acord cu clasificarea Federaţiei Europene de Parodontologie (15) şi s-au apreciat stadiul şi gradul afectării parodontale (16).

Caracteristicile leziunilor parodontale au fost apreciate urmărind identificarea următoarelor modificări:

1) Procentul de situsuri cu sângerare spontană sau la sondare

2) Prezenţa plăcii bacteriene şi depozitului de tartru situat subgingival, supragingival şi total

3) Recesia marginii gingivale, apreciată la joncţiunea cement/smalţ

4) Mobilitatea dentară

- Gradul 1 - vestibulo-orală

- Gradul 2 - vestibulo-orală şi aproximală

- Gradul 3 - vestibulo-orală, aproximală şi axială

5) Sondare nivel ataşament clinic cu aprecierea adâncimii de sondare la şase situsuri/dinte (uşoară 1-2 mm, medie 3-4 mm, gravă $>5 \mathrm{~mm}$ )

6) Implicarea furcaţiei radiculare cu penetrarea orizontală a sondei

- Gradul $1<3 \mathrm{~mm}$

- Gradul $2>3 \mathrm{~mm}$

- Gradul 3 - până la capăt între două rădăcini

7) Ocluzia dentară modificată

Leziunile constatate la nivelul parodonţiului au fost clasificate după gravitate şi amploare, având în vedere imaginea evoluţiei etapizate a bolii, sub influenţa hipotiroidismului şi a autoanticorpilor tiroidieni cu impact potenţial asupra plăcii bacteriene și indicelui de igienă orală, inițiatoare a procesului inflamator/autoimun.

Pacienţii au fost clasificaţi după gravitatea si extinderea leziunilor parodontale:

- PC incipientă - cu sângerare gingivală, recesia marginii gingivale, depozitul de tartru

- PC de intensitate medie - după adâncimea de sondare a pungilor parodontale cu ataşament dentar afectat

- PC avansată, cu furcaţie radiculară şi ocluzie dentară modificată.

Studiul autoimunităţii nespecifice a fost efectuat dozând calitativ anticorpii ANA (,,antinuclear antibody") prin testul EliA ${ }^{\mathrm{TM}}$ Symphony, reactivul folosit conţinând proteine umane recombinate RNP, Ro, La, Centromer B, SCL-70, Jo-1 şi proteine purificate nativ $\mathrm{Sm}$. Rezultatele exprimate sub forma unui index au avut următoarele valori de referinţă: $<0,7$ - negativ; 0,7-1 echivoc; $>1$ pozitiv.

\section{Analiza statistică}

Pentru modificările constatate prin examen clinic a fost utilizat testul $\mathrm{T}$ pentru variabile continue apreciate comparativ. Semnificaţia statistică a fost determinată la o valoare $\mathrm{p}<0,001$, iar $\mathrm{p}<0,05 \mathrm{~s}-\mathrm{a}$ considerat o posibilă corelaţie statistică. O serie de valori au fost exprimate procentual (\%) şi/sau ca valoare medie \pm deviaţia standard (DS).

Pentru interpretarea rezultatelor obţinute având în vedere aprecierea gravităţii şi amplorii leziunilor parodontale, au fost folosite: testul Chi pătrat pentru parametrii nonnumerici, fiind analizată distribuţia frecvenţelor; regresia liniară - simplă şi multifactorială (coeficientul r Pearson); testul ANOVA pentru compararea rezultatelor din cele două loturi.

\section{REZULTATE}

O distribuţie comparativă a leziunilor parodontale sub aspect procentual, cu semnificaţia lor statistică, este redată în tabelul 1 .

Din datele prezentate, se remarcă o heterogenitate a distribuţiei valorilor înregistrate pentru diversele tipuri de leziuni constatate în ambele loturi studiate. Aprecierea comparativă a leziunilor identificate conform protocolului de studiu între cele două loturi de pacienţi (1 şi 2) sub aspectul semnificaţiei statistice a remarcat o preponderenţă a leziunilor considerate evoluate sub aspectul gravităţii, în special în cadrul lotului 1 comparativ cu lotul 2.

O posibilă implicare a nivelului seric al autoanticorpilor tiroidieni a fost apreciat ca având valori 
TABEL 1. Semnificația statistică a tipului lezional în cele două loturi de studiu

\begin{tabular}{|c|c|c|c|}
\hline Tip leziune & $\begin{array}{c}\text { Lot } 1 \mathrm{n}=109 \\
(\%)\end{array}$ & $\begin{array}{c}\text { Lot } 2 \mathrm{n}=91 \\
(\%)\end{array}$ & $\mathbf{p}$ \\
\hline \multicolumn{4}{|l|}{$\begin{array}{l}\text { 1. Sângerare procent } \\
\text { situsuri }\end{array}$} \\
\hline Spontan & $45,8 \%(n=50)$ & $42,8 \%(n=39)$ & NS \\
\hline La sondare & $38,5 \%(n=42)$ & $60,4 \%(n=55)$ & $\mathrm{P}<0,001^{* *}$ \\
\hline 2. Prezența placă bacteriană/depozite tartru & $87,1 \%(n=95)$ & $90,1 \%(n=82)$ & NS \\
\hline 3. Recesia marginii gingivale & $93,5 \%(n=102)$ & $67 \%(n=61)$ & $p<0,001^{*}$ \\
\hline \multicolumn{4}{|l|}{ 4. Mobilitatea dentară } \\
\hline Grad 1 & $20,2 \%(n=22)$ & $34 \%(n=33)$ & $p<0,05$ \\
\hline Grad 2 & $48,6 \%(n=53)$ & $17,5 \%(n=31)$ & $p<0,001 *$ \\
\hline Grad 3 & $29,3 \%(n=32)$ & $30,7 \%(n=16)$ & NS \\
\hline \multicolumn{4}{|l|}{ 5. Profunzimea pungilor parodontale la sondare } \\
\hline Grad 1 & $13,7 \%(n=15)$ & $30,7 \%(n=28)$ & $p<0,001^{* *}$ \\
\hline Grad 2 & $48,6 \%(n=53)$ & $29,6 \%(n=27)$ & $p<0,001 *$ \\
\hline Grad 3 & $27,5 \%(n=30)$ & $14,2 \%(n=13)$ & $p<0,001^{*}$ \\
\hline 6. Implicarea furcației radiculare & $57,8 \%(n=63)$ & $11 \%(n=10)$ & $\mathrm{p}<0,001^{*}$ \\
\hline 7.0cluzia dentară modificată & $71,5 \%(n=78)$ & $19,7 \%(n=18)$ & $p<0,001^{*}$ \\
\hline
\end{tabular}

NS - nesemnificativ statistic

medii pentru pacienţii cu leziuni ,iniţiale“ și ,,agravate" (Tabel 2).

TABEL 2. Implicarea nivelului seric al autoanticorpilor tiroidieni în leziunile parodontale inițiale şi agravate semnificație statistică - Lot 1 studiu $(n=109)$

\begin{tabular}{|l|c|c|}
\hline & $\begin{array}{c}\text { ATPO } \\
\text { (valori mediane) }\end{array}$ & $\begin{array}{c}\text { ATg } \\
\text { (valori mediane) }\end{array}$ \\
\hline $\begin{array}{l}\text { Recesia marginii } \\
\text { gingivale, } \mathrm{n}=102\end{array}$ & $143 \pm 22$ & $211 \pm 27$ \\
\hline $\begin{array}{l}\text { Ocluzie dentară } \\
\text { modificată, } \mathrm{n}=78\end{array}$ & $136 \pm 18$ & $543 \pm 31$ \\
\hline $\mathrm{P}$ & NS & $<0,001$ \\
\hline
\end{tabular}

Implicarea posibilă a autoanticorpilor antitiroidieni (ATPO/ATg) în realizarea leziunilor identificate conform protocolului în cazul pacienţilor din lotul 1 de studiu pare probabilă în special în cazul ATg.

În lotul de studiu ( $\mathrm{n}=109)$, s-a urmărit corelarea leziunilor parodontale cu nivelul seric hormonal tiroidian (Tabel 3).

O posibilă implicare a disfuncţiei tiroidiene la pacienţii cu TCA în dezvoltarea leziunilor parodontale s-a dovedit nesemnificativă pentru aceleaşi tipuri de leziuni, iniţială - recesia marginii gingivale, şi agravată - ocluzia dentară modificată, în cazul pacienţilor cu normofuncţie şi al celor cu tireotoxicoză din lotul de studiu 1. Pentru pacienţii hipotiroidieni, s-a constatat o semnificaţie statistică posibilă în favoarea recesiei marginale (testul $\chi^{2}$ al asocierii, $\mathrm{p}=0,05)$.

Pacienţii evaluaţi conform obiectivelor studiului, sub aspectul leziunilor PC corelate cu caracteristicile hormonale şi ale autoimunităţii la pacienţii cu TCA, au fost clasificaţ̧i după intensitatea şi amploarea leziunilor parodontale constatate:

- PC incipientă (sângerare gingivală, recesia marginii gingivale, depozitul de tartru) - lotul $1-35$ cazuri $(32 \%)$; lotul $2-27$ cazuri $(30 \%)$.

- PC de intensitate medie (pungi parodontale, ataşament dentar afectat - lotul $1-58$ cazuri (57\%); lotul 2 - 52 cazuri (53\%).

- PC agravată (furcaţia radiculară, ocluzie dentară modificată) - lotul 1 - 16 cazuri $(15 \%)$, lotul $2-12$ cazuri (13\%).

Distribuţia leziunilor parodontale (gravă, medie, incipientă) la pacienţii din cadrul loturilor de studiu a urmărit evidenţierea diferenţelor procentuale ale specificului fiecărui tip lezional (Fig. 1).

Toate cele trei categorii de leziuni au fost întâlnite mai frecvent la pacienţii din lotul 1 comparativ cu pacienţii din lotul martor $(p=0,043)$. În ambele loturi au prevalat leziunile de intensitate medie.

TABEL 3. Corelarea disfuncției tiroidiene la pacienții cu leziuni parodontale inițiale şi agravate

\begin{tabular}{|l|c|c|c|}
\hline Lot studiu $(\mathrm{n}=109)$ & $\begin{array}{c}\text { Normofuncție } \\
{[\mathrm{TSH}: 0,24-4,2 \mu \mathrm{UI} / \mathrm{ml})}\end{array}$ & $\begin{array}{c}\text { Hipotiroidie } \\
{[\mathrm{TSH}: 24 \pm 8,12 \mu \mathrm{UI} / \mathrm{ml}]}\end{array}$ & $\begin{array}{c}\text { Tireotoxicoză } \\
{[\mathrm{TSH}: 0,08-0,04 \mu \mathrm{UI} / \mathrm{ml}]}\end{array}$ \\
\hline Recesia marginii gingivale $(\mathrm{n}=102)$ & $\begin{array}{c}27 \\
(52,2 \%)\end{array}$ & $\begin{array}{c}27 \\
(24,7 \%)\end{array}$ \\
\hline Ocluzia dentară modificată $(\mathrm{n}=78)$ & 52 & 15 & $16,5 \%)$ \\
& $(47,7 \%)$ & $(13,7 \%)$ & $(10,1 \%)$ \\
\hline$p=0,05$ & \multicolumn{3}{|c}{} \\
\hline
\end{tabular}




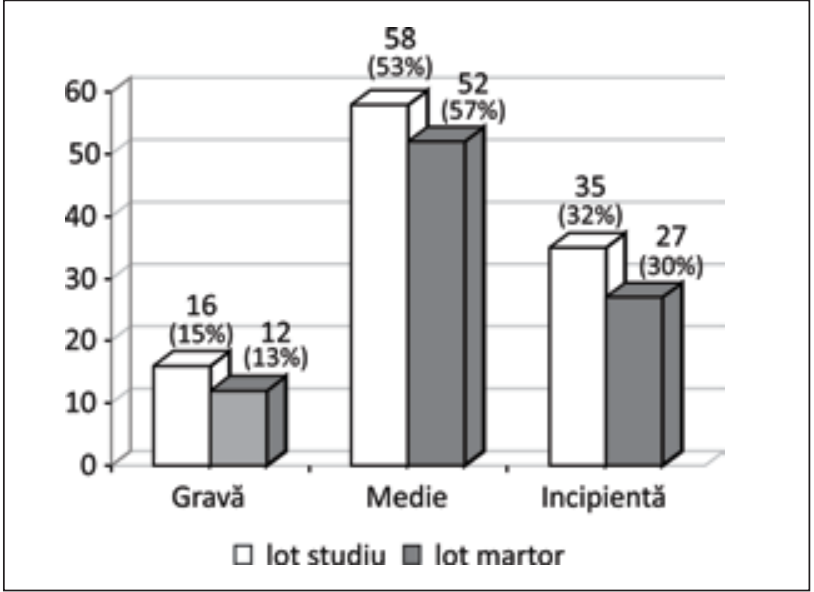

FIGURA 1. Parodontita cronică - caracteristici de expresie - lotul de studiu/lotul martor

Studiul diferenţiat al leziunilor parodontale în funcţie de sexul pacienţilor (Fig. 2) ar putea preciza implicări diferenţiate ale unor caracteristici specifice fiecărui sex - profil hormonal, particularităţi metabolice, factori aleatori sau specifici (ocupaţionali, de comportament etc.).

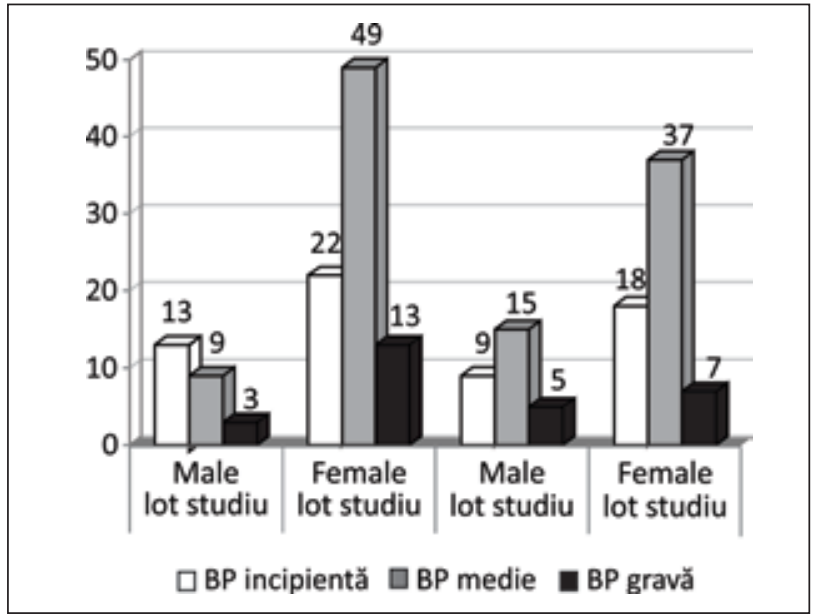

FIGURA 2. Distribuția comparativă a leziunilor parodontale în funcție de sexul pacienților

Sub aspect procentual, în lotul de studiu, bărbaţii au prezentat PC incipientă (12\%); PC medie
(8,2\%); PC gravă $(2,7 \%)$. Femeile din lotul de studiu au avut: 20,1\% PC incipientă, 45\% PC medie şi $12 \%$ PC gravă. În lotul martor, a predominat PC de intensitate medie la 16,4\% dintre bărbaţi şi $40,6 \%$ dintre femei.

Distribuția leziunilor parodontale exprimate procentual a fost apreciată în funcție de vârsta pacienților (Fig. 3).

Luând în calcul criteriul vârstei privind intensitatea leziunilor parodontale, s-a observat că leziunile caracterizate drept incipiente ale PC au fost întâlnite prioritar la grupa tânără de vârstă (24-31 ani), iar cele de intensitate medie şi de intensitate agravată la grupele de vârstă 32-39 ani şi 40-48 ani. Caracterizarea leziunilor parodontale - incipiente, de intensitate medie, gravă - după criteriul vârstei pacienților subliniază rolul duratei de evoluție a bolii în realizarea complicațiilor.

Prin regresie liniară monofactorială (coeficientul r Pearson), s-au testat raporturile de dependenţă între OHI-s (în intervalul de valori 2-6) şi următoarele variabile cu efect potențial asupra dezvoltării şi agravării leziunilor parodontale: vârsta pacienţilor (Fig. 4), funcţia tiroidiană (TSH) (Fig. 5) şi autoimunitatea tiroidiană (ATPO, ATg) (Fig. 6).

Dacă vârsta pacienților cuprinde efecte cumulative ale factorilor patogeni ipotetic activi direct proporțional cu durata lor de acțiune, funcția tiroidiană alterată, prezența şi particularitățile de expresie ale autoimunității tiroidiene explorează şi identifică un potențial efect patogen specific, asociat bolii autoimune tiroidiene.

Indicele de igienă orală a fost apreciat în corelaţie cu vârsta, fiind reprezentat grafic în fig. 4).

Sub aspectul vârstei pacienţilor, se remarcă o interdependenţă medie între OHI-s şi aceasta $(\mathrm{r}=0,63 ; \mathrm{p}=0,018)$.

Implicarea disfuncţiei tiroidiene asupra indicelui de igienă orală s-a efectuat luând în calcul valoarea serică a TSH (Fig. 5).

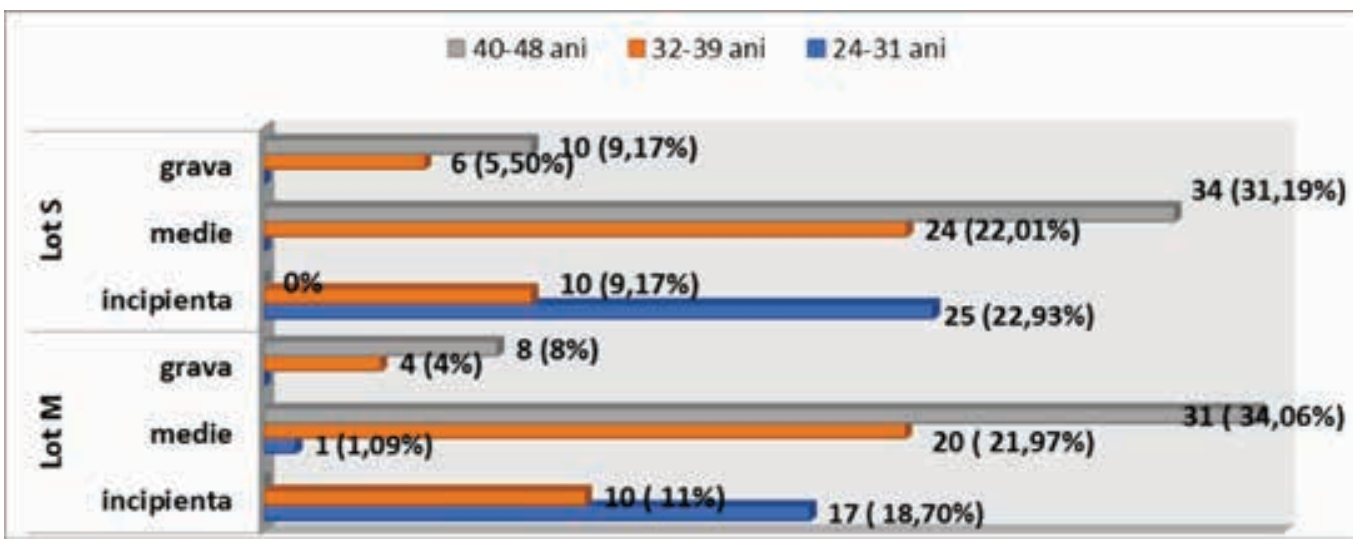

FIGURA 3. Distribuția comparativă a leziunilor parodontale în funcție de vârstă 


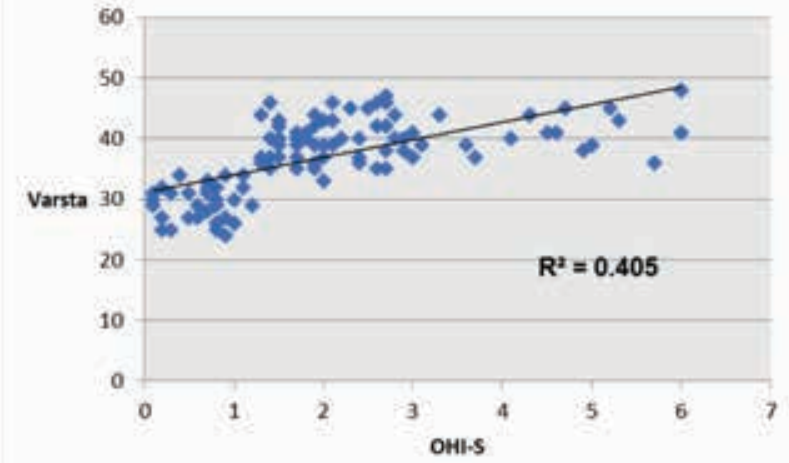

FIGURA 4. Corelația între vârsta pacienților şi OHI-s (coeficient r Pearson)

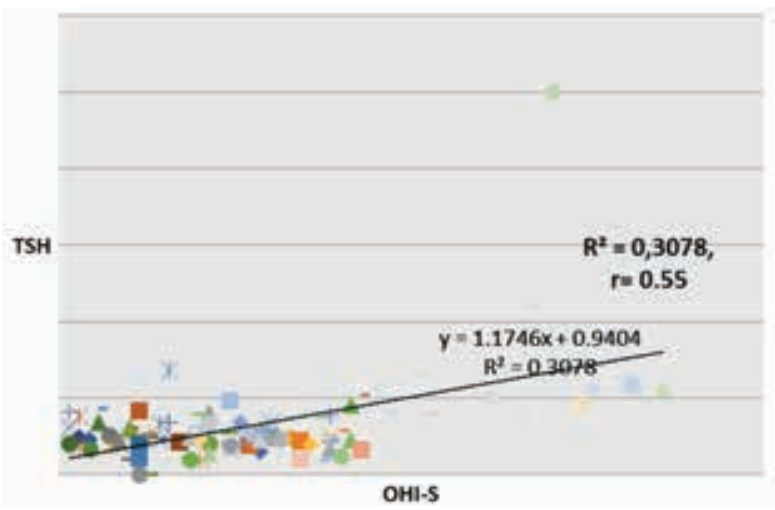

FIGURA 5. Corelația între TSH şi OHI-s (coeficient $r$ Pearson)

Funcţia tiroidei, apreciată prin valoarea medie a nivelului seric TSH înregistrat peste nivelul maxim normal ( $>4,2 \mathrm{mUI} / \mathrm{ml})$, a determinat în condiţii de hipotiroidism o interdependenţă medie între OHI-s şi TSH $(r=0,55 ; \mathrm{p}=0,0003)$.

Un eventual rol al autoanticorpilor antitiroidieni asupra indicelui de igienă orală a fost explorat şi reprezentat grafic la pacienţii cu TCA asociind PC (Fig. 6).

Luând în calcul valorile serice medii ATPO şi ATg considerate individual la pacienţii lotului 1, nu a fost evidenţiată o relaţie proporţională cu valoarea OHI-s. Luând în calcul implicări monofactoriale ale unor potenţiali ,,agresori“" cum ar fi vârsta pacienţilor, funcţia tiroidiană şi prezenţa autoimunităţii tiroidiene, datele statistice au demonstrat valori de interdependenţă medie (vârsta pacienţilor, nivelul seric TSH) sau chiar absentă (autoanticorpi tiroidieni).

S-a considerat, astfel, necesară aprecierea corelaţiei OHI-s cu parametrii tiroidieni studiaţi sub aspectul implicării multifactoriale (Fig. 7).

Analizând relaţia dintre parametrii obţinuţi în studiul caracteristicilor TCA la pacienţii lotului de studiu prin regresie liniară multifactorială (test ANOVA), s-a constatat o relaţie direct proporţională între OHI-s şi TSH, ATPO, ATg $(r=0,56$; $\mathrm{p}=0,001)$.

Adăugarea criteriului vârstă la parametrii studiaţi a luat în calcul şi durata evoluţiei bolilor studiate PC şi TCA (Fig. 8).

Alături de parametrii tiroidieni studiați, luând în considerare şi vârsta pacienţilor, interdependenţa lor a fost mult mai ,strânsă“", cu înaltă semnificație statistică $(r=0,78 ; p<0,001)$. Aprecierea prezenţei autoimunităţii nespecifice a constat în dozajul calitativ al anticorpilor antinucleari (ANA). Incidenţa cazurilor cu nivel seric pozitiv pentru ANA a fost de $11 \%(n=12)$ în lotul de studiu şi de $2,2 \%(n=2)$ in lotul martor, repartiţia pe sexe fiind de $83,3 \%$ la sexul feminin şi $16,7 \%$ la sexul masculin.

\section{DISCUȚII}

În acord cu obiectivele propuse pentru realizarea studiului, rezultatele au fost interpretate sub aspectul incidenței şi al particularităților de expresie a leziunilor parodontale întâlnite la pacienții cu

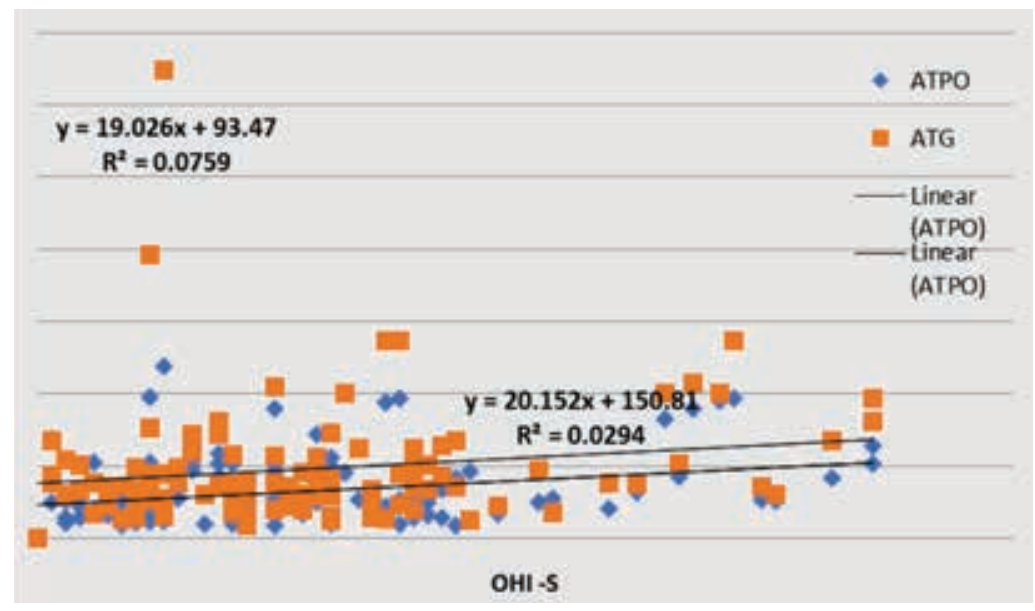

FIGURA 6. Corelația între nivelul ATPO, ATg şi OHI-s 


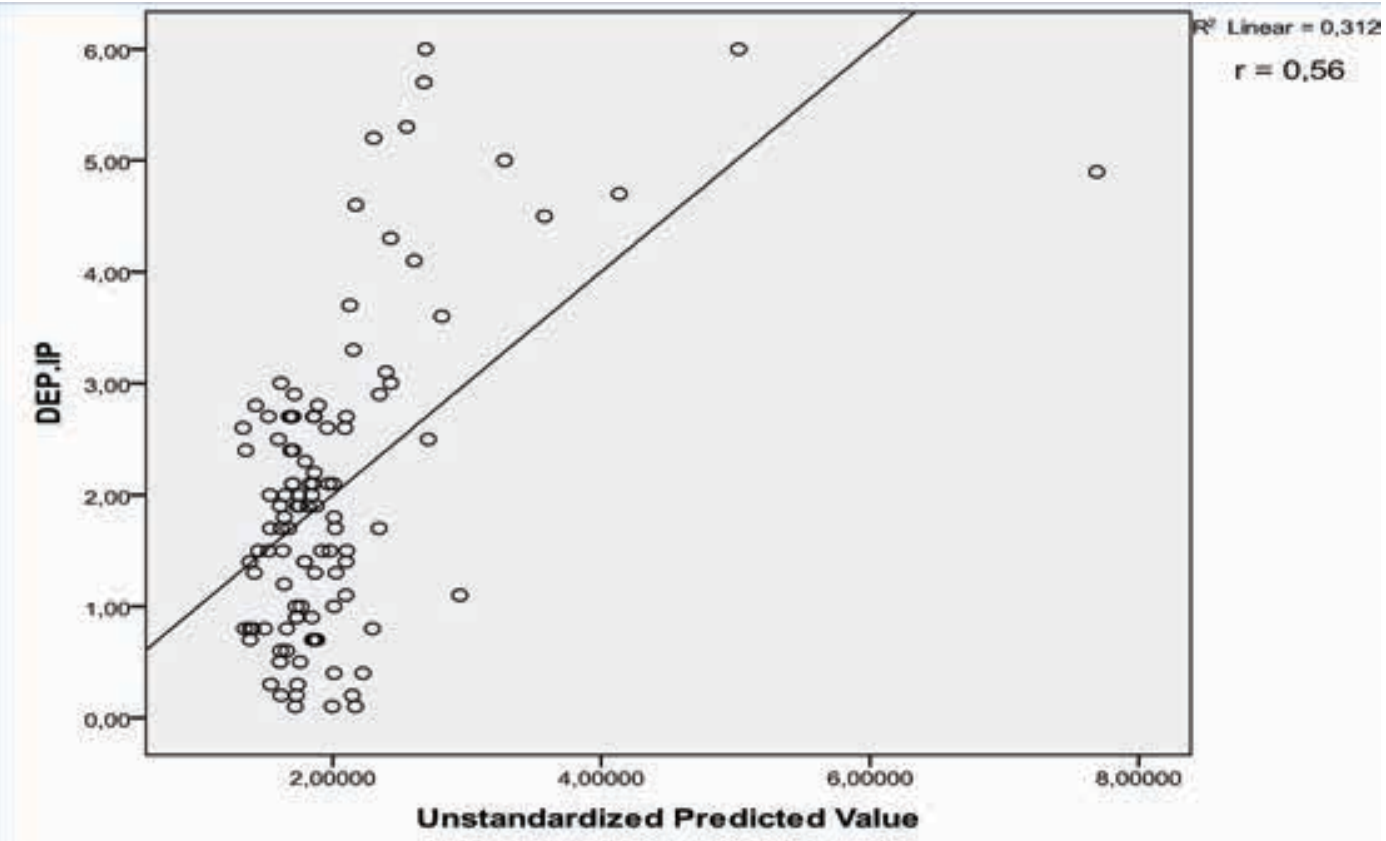

FIGURA 7. Corelația dintre OHI-s, TSH, ATPO şi ATG (regresie multifactorială liniară)

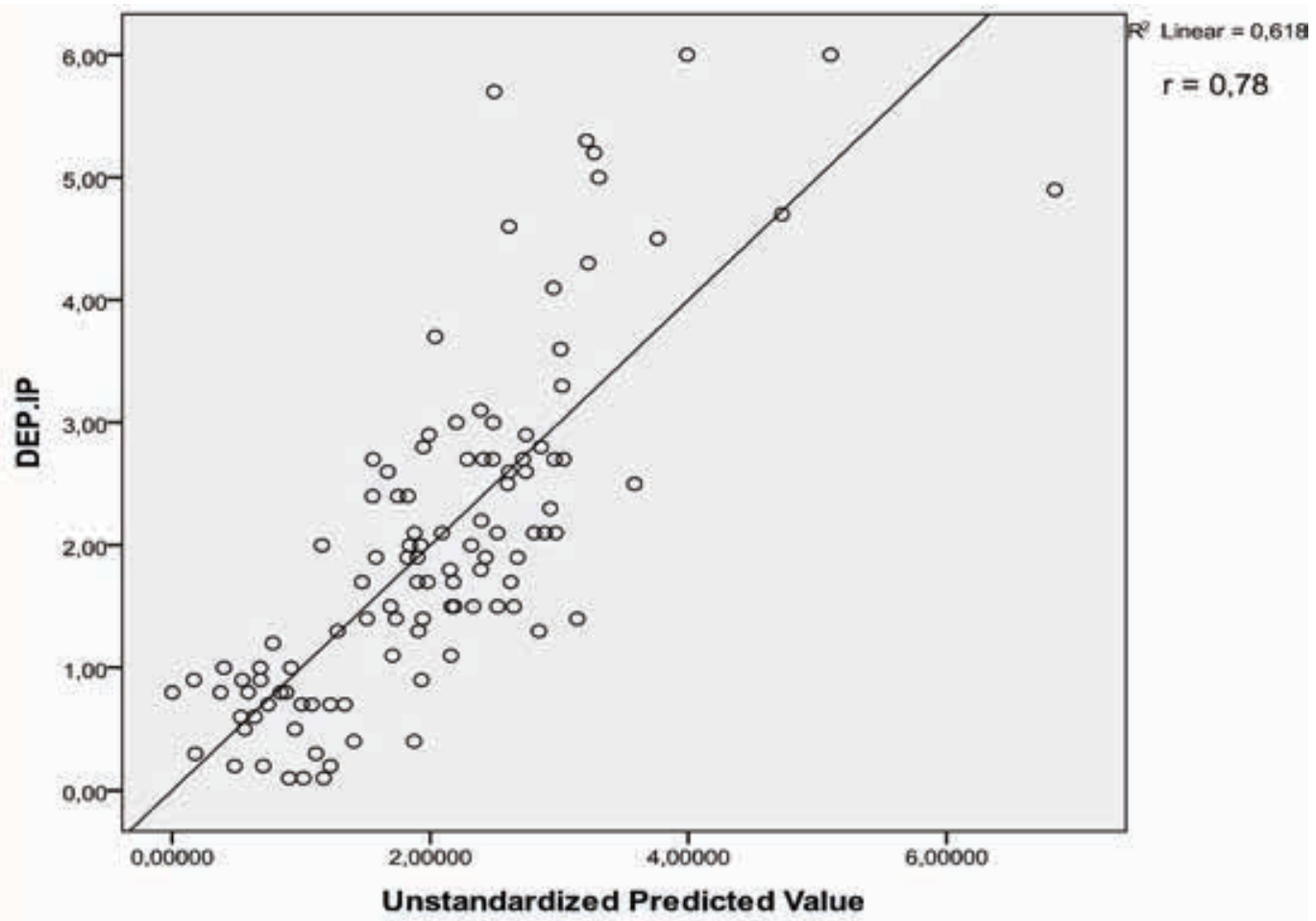

FIGURA 8. Corelația dintre OHI-s, TSH, ATPO, ATg şi vârsta (regresie liniară multifactorială)

tiroidită cronică autoimună. Aprecierea comparativă a parametrilor studiați între cele două loturi de pacienți identifică posibile intercondiționări patogenice între boala autoimună tiroidiană şi parodontită. Studii similare bazate pe observația clinică $(8,9,12,13)$ asociază cele două boli sub raport de incidență şi intercondiţionare patogenică.

Caracteristicile leziunilor parodontale constatate clinic la cele două loturi de studiu au fost hete- rogene sub aspectul semnificației lor statistice. S-au înregistrat valori semnificative statistic $(\mathrm{p}<0,001)$ în favoarea lotului 1 de studiu pentru recesia marginii gingivale, mobilitatea dentară gradul 2, profunzimea pungilor parodontale la sondare gradul 2 şi 3, implicarea furcaţiei radiculare şi ocluzia dentară modificată. Semnificație statistică $(p<0,001)$ în favoarea lotului 2 de studiu a fost observată pentru sângerarea la sondare şi profunzi- 
mea pungilor parodontale la sondare gradul 1, precum şi o posibilă corelație statistică $(p<0,05)$ pentru mobilitatea dentară gradul 1 .

Se remarcă o heterogenitate a rezultatului examenului clinic al pacienților examinați din punct de vedere dentar în distribuția leziunilor constatate şi apreciate comparativ între cele două loturi de pacienți. Valorile procentuale şi semnificația statistică a unor tipuri lezionale au fost observate prioritar în rândul pacienților cu PC asociind şi TCA. Aceste date sunt în acord şi cu observații similare obținute în cadrul altor studii (13).

De remarcat prezența depozitului de tartru şi, implicit, a plăcii bacteriene la pacienții cu PC din ambele loturi, fără diferențe semnificative statistic. Placa dentară este considerată factor de inițiere şi progresie a leziunilor întâlnite în PC proporțional cu întinderea ei subgingival, supragingival şi total $(1,6)$, fiind corelată cu vârsta pacienţilor şi procesul inflamator şi imun alterat $(18,19)$.

Aceste procese patologice sunt însă întâlnite în ambele boli - PC şi TCA -, având substrat inflamator/autoimun $(2,4,13,14,21,23)$.

Evaluarea implicării posibile a autoanticorpilor tiroidieni în realizarea variabilității leziunilor parodontale la pacienții cu TCA a luat în calcul aprecierea comparativă a valorilor medii ale nivelului seric ATPO şi, respectiv, AcTg înregistrate la pacienții cu leziuni parodontale considerate „iniţiale“ şi, respectiv, pacienți cu leziuni parodontale considerate ,agravate“ (Tabel 2). Pentru aceste tipuri lezionale, semnificația statistică a fost obținută doar pentru nivelul seric al AcTg. Posibila implicare a autoimunității tiroidiene în boli autoimune netiroidiene prin prezența AcTg atestă un efect sistemic în realizarea complicațiilor extratiroidiene întâlnite la pacienții cu TCA (17), subliniind probabilitatea substratului autoimun comun de dezvoltare pentru PC şi TCA (13).

Variaţiile cantitative şi particularitățile acțiunii fluctuante a autoanticorpilor tiroidieni, precum şi responsivitatea individuală la acțiunea lor pot explica heterogenitatea leziunilor parodontale la pacienții cu TCA (21). Prezența leziunilor parodontale şi a modificărilor compoziționale ale salivei cu efect oxidativ la un lot de paciente de sex feminin, suferind de TCA, dar cu funcție tiroidiană normală, subliniază posibilul rol determinant al autoimunității tiroidiene în realizarea PC (22). O concluzie corelabilă implicării diferențiate a autoimunității tiroidiene în mod exclusiv ar implica o explorare populațională extinsă şi individualizată.
În realizarea leziunilor întâlnite la pacienții cu PC şi TCA, datele din literatură implică alterarea nivelului seric hormonal tiroidian $(8,10,11,12)$.

Dacă hipotiroidia realizează modificări de tip trofic la nivel parodontal, favorizând efectul „trigger" bacterian (6) şi o serie de mediatori inflamatori $(3,4)$, cu distrugeri initiate de metaloproteinaze (8), la care se adaugă modificări ale microbiomului oral proporțional cu nivelul seric crescut $\mathrm{TSH}$, asociind o creştere a rezistenței de acțiune la insulină (24), hipertiroidia intervine prin modificări circulatorii locale, favorizând leziuni trofice, sângerări gingivale (9) şi resorbție osoasă alveolară intensificată $(5,12)$.

În acest sens, o posibilă implicare a disfuncției tiroidiene (apreciată prin nivelul seric TSH înregistrat la pacienții cu TCA asociind PC) în realizarea leziunilor parodontale ,iniţiale“ şi ,agravate“ nu a constatat valori semnificative statistic pentru normofuncția şi, respectiv, excesul hormonal tiroidian (Tabel 3).

Este important de precizat că majoritatea cazurilor studiate au fost cu valori serice hormonale tiroidiene normale $(57 \%)$; cu valori caracteristice hipotiroidiei - $27 \%$ şi cu tireotoxicoză $-18 \%$. Disfunctiile tiroidiene au fost de intensitate subclinică, iar în rândul pacienților cu TCA 91\% dintre aceştia erau sub tratament tiroxinic. Pentru pacienții cu hipotiroidie, s-a constatat o posibilă corelație statistică pentru recesia gingivală $(\mathrm{p}<0,05)$. Deşi numărul redus de cazuri studiate în faze evolutive diferite ale bolii parodontale, corelat $\mathrm{cu}$ variațiile nivelului hormonal tiroidian $\mathrm{cu}$ evoluție naturală şi corectată tiroxinic, nu precizează o implicare directă, lezională, în realizarea şi progresia PC, nu se poate exclude rolul hormonilor tiroidieni în contextul hipotiroidiei în iniţierea şi agravarea leziunilor parodontale (10).

Pentru evidențierea caracterului dinamic şi a evoluției etapizate a PC, pacienții au fost clasificați în funcție de intensitatea leziunilor parodontale: incipiente, de intensitate medie şi agravate. Această clasificare a fost efectuată în acord cu recomandările clinice (15) şi clasificarea leziunilor parodontale după stadiul evolutiv şi gradul afectării (16).

Toate cele trei categorii de leziuni au fost identificate mai frecvent la pacienții din lotul 1 de studiu $(n=109)$ față de pacienţii lotului $2(n=91)$. Semnificaţia statistică stabilită a fost $p=0,043$. În ambele loturi, au prevalat leziunile parodontale de intensitate medie. Rezultatele obținute sunt în acord cu posibila implicare a TCA în realizarea şi variabilitatea de expresie a leziunilor parodontale, 
conform rezultatelor explorării clinice analizate anterior. Implicarea unor posibile variabile active individual în realizarea caracteristicilor semiologice urmărite la pacienții cu PC a luat în calcul criteriul sexului pacienților (Fig. 3). Pentru sexul masculin, leziunile incipiente au predominat (12\%), fiind urmate de leziunile de intensitate medie $(8,2 \%)$ şi, respectiv, gravă $(2,7 \%)$. Pentru sexul feminin, au predominat leziunile de intensitate incipientă $(20,1 \%)$, gravă $(12 \%)$ şi medie $(4,5 \%)$.

În lotul martor, a predominat PC de intensitate medie la 16,4\% dintre bărbaţi şi la 40,6\% dintre femei.

Numărul bărbaților investigați a fost redus acesta fiind un element limitativ. Particularitățile de expresie a TCA la femei includ frecvența bolii şi asocierea specificului variaţiilor hormonale extratiroidiene (2). Afectarea prioritară a sexului feminin în ambele loturi de studiu sub aspectul intensității leziunilor parodontale, cu o incidență crescută a acestora în cadrul lotului 1 , asociind TCA cu PC, implică posibil TCA ca mecanism patogenic de ,intensificare“ în realizarea leziunilor de PC, fapt constatat şi în alte studii (13).

În aceeaşi manieră de studiu, s-a luat în calcul criteriul vârstei privind implicarea acesteia ca durată de evoluție a PC. În ambele loturi de studiu, leziunile incipiente au fost întâlnite la grupa tânără de vârstă: lot $1-22,9 \%$; lot $2-18,7 \%$. Leziunile de intensitate medie au fost de 31,19\% la grupa mare de vârstă - lotul 1 şi, comparativ, 34,06\% la grupa mare de vârstă - lotul 2. Afectarea severă s-a constatat la $9,17 \%$ dintre pacienții cu grupă mare de vârstă faţă de $8,8 \%$ dintre pacienții seniori ai lotului 2 (martor). Intensitatea leziunilor parodontale constatate după criteriul vârstei nu sunt semnificativ diferite între cele două categorii de pacienți studiați, vârstei atribuindu-i-se implicarea unor factori patogeni cumulativi care pot fi individuali şi aleatorii (19).

Placa dentară este o variabilă importantă cu diferenţă de fază evolutivă şi individualitate de expresie ca urmare a unor factori determinanți cum ar fi vârsta pacientului, specificul microbiomului cavităţii orale, tulburări hormonale tiroidiene, hiperrăspunsul inflamator şi imunitar la agresiunea microbiană etc. $(3,4,6)$. Măsurile de igienă orală neadecvate întâlnite adesea la pacienţii cu PC şi la cei cu disfuncții homonale, prioritar tiroidiene, sunt corelate cu severitatea PC şi întinderea plăcii dentare (20). Studiul indicelui de igienă orală simplificat (OHI-s) s-a considerat util în stabilirea relației intercauzale între PC şi TCA $(6,14,19,20)$.
Raporturile de interdependență între OHI-s, măsurat în intervalul de valori 2-6, şi vârsta pacienților, nivelul seric TSH corelat cu statusul funcțional tiroidian şi autoimunitatea tiroidiană, reprezentată de nivelul seric mediu al ATPO şi $\mathrm{AcTg}$, apreciate prin regresia liniară monofactorială, au luat în calcul implicarea acestor variabile în realizarea plăcii dentare şi, implicit, a leziunilor parodontale. Interdependența variabilelor explorate a fost de intensitate medie pentru vârsta pacienților $(r=0,63 ; p=0,018)$ (fig. 4), intensitate medie pentru hipotiroidie $(r=0,55 ; p=0,0003)$ (fig. 5) şi nu s-a constatat o relaţie proporțională cu valoarea OHI-s a nivelului seric mediu al ATPO şi AcTg (fig. 6). Aceste variabile apreciate individual nu conferă un rol principal unui anumit factor patogen în dezvoltarea leziunilor de PC la pacienții cu PC asociind sau nu şi TCA.

Ca urmare, s-a considerat necesară aprecierea corelației OHI-s cu parametrii tiroidieni studiați sub aspectul implicării multifactoriale.

Regresia liniară multifactorială (ANOVA-test) a stabilit o relație direct proporțională între OHI-s şi TSH, ATPO, AcTg ( $r=0,56 ; p<0,001)$ (fig. 7), adăugarea criteriului vârstei pacienților (fig. 8) subliniind o interdependență mai strânsă, cu o înaltă semnificație statistică $(r=0,78 ; p<0,001)$.

Rezultatele menționate subliniază patogenia multifactorială a PC, microbiomului salivar revenindu-i un rol esenţial în declanşarea procesului patogenic parodontal (14). Dacă vârsta pacienților şi o serie de practici greşite afectează componentele cavității orale (19), tulburările funcționale tiroidiene şi prezența autoanticorpilor tiroidieni pot exercita un efect direct la nivel parodontal (10) sau indirect, prin alterarea compoziției salivei, cu intensificarea efectelor oxidative (22), ori modificarea microbiomului cavității orale (21), asociind insulinorezistenţă şi biodiversitate taxonomică (24). Luați individual, factorii studiați cu efect lezional potențial parodontal prezintă semnificații statistice dificil de sistematizat. Aprecierea determinării plurifactoriale a procesului lezional parodontal întâlnit la pacienții cu tiroidită cronică autoimună capătă valoare semnificativă statistic, subliniind complexitatea etiopatogeniei parodontitei cronice.

Procesul autoimunității nespecifice constând în prezența anticorpilor antinucleari ANA nu s-a corelat $\mathrm{cu}$ severitatea leziunilor parodontale $(\mathrm{p}=0,10)$. Interpretarea acestui rezultat trebuie să țină cont însă de aspectul limitativ al numărului redus de cazuri evaluate pentru acest parametru, deşi date din literatura de specialitate atestă prezența 
ANA în populatia generală de până la $5 \%$ pentru tineri şi până la $50 \%$ pentru persoanele cu vârsta de peste 80 ani (9).

Limitările studiului sunt reprezentate de numărul redus de cazuri studiate în raport cu o patologie având o valoare epidemiologică extinsă pentru ambele boli, PC şi TCA. De asemenea, evoluţia etapizată a PC este greu de caracterizat la momentul explorării, procesul patologic fiind evolutiv.

\section{CONCLUZII}

Leziunile parodontale cu incidenţă crescută şi gravitate sporită întâlnite la pacienţii cu tiroidită cronică autoimună comparativ cu pacienţii fără patologie tiroidiană subliniază posibila intricare etiopatogenică a celor două boli.

Prezenţa anticorpilor antitiroidieni - ATPO şi ATg - exercită un efect mai intens asupra OHI-s Conflict of interest: none declared Financial support: none declared

\section{BIBLIOGRAFIE}

1. Carranza FA, Takei N, Newman MG. Clinical Periodontology, 10th ed. Philadelphia: B Saunders Company-Elsevier Inc, 2006.

2. Hafler D, Housley W, Marson A. Genetic basis of autoimmunity. J Clin Invest. 2015;125(6):2234-2241.

3. Yucel-Lindberg T, Båge T. Inflammatory mediators in the pathogenesis of periodontitis. Expert Rev Mol Med. 2013 Aug 5;15:e7.

4. Tâlvan ET, Mohor $C$, Chisnoiu $D$, et al. Expression of interleukin (IL)-1 $\beta$, IL-8, IL-10 and IL-13 in chronic adult periodontitis progression. Arch Med. 2017:9(34):1-8.

5. Hienz SA, Paliwal S, Ivanovski S. Mechanisms of Bone Resorption in Periodontitis. J Immunol Res. 2015;2015:615486.

6. Tribble GD, Lamont RJ. Bacterial invasion of epithelial cells and spreading in periodontal tissue. Periodontology 2000. 2010 Feb;52(1):68.

7. Du M, Wang Y, Liu Z, et al. Effects of IL-1 $1 \beta$ on MMP-9 expression in cementoblast-derived cell line and MMP-mediated degradation of type I collagen. Inflammation. 2019 Apr:42(2):413-25.

8. Shcherba V, Kyryliv M, Bekus I, et al. A Comparative Study of Connective Tissue Metabolism Indices in Experimental ComorbidityFree Periodontitis and Periodontitis Combined with Thyroid Dysfunction. Journal of Medicine and Life. 2020 Apr;13(2):219.

9. Kim JY, Park YB, Lee SW. Thyroid Dysfunction in Patients with Antineutrophil Cytoplasmic Antibody-associated Vasculitis: A Monocentric Retrospective Study. J Rheumatol. 2019 Sep; 46(9):1248-1250.

10. Aldulaijan HA, Cohen RE, Stellrecht EM, Levine MJ, Yerke LM. Relationship between hypothyroidism and periodontitis: A scoping review. Clin Exp Dent Res. 2020 Feb;6(1):147-157.

11. Yerke L, Levine M, Cohen R. MON-616 Potential Relationship between Hypothyroidism and Periodontal Disease Severity. J Endocr Soc. 2019 Apr 30;3(Suppl 1):MON-616.

12. Monea A, Elod N, Sitaru A, et al. Can thyroid dysfunction induce periodontal disease?. European Scientific Journal. 2014 May $1 ; 10(15)$

13. Patil BS, Patil S, Gururaj TR. Probable autoimmune causal relationship between periodontitis and Hashimoto`s thyroidits: dacă sunt luate în considerare vârsta pacienţilor şi hipofuncţia tiroidiană.

Anticorpii antinucleari rămân imprecis delimitaţi drept cauză/efect în patologia autoimună parodontală şi tiroidiană, conform rezultatelor studiului nostru.

În acord cu mutiplele studii din literatura de specialitate privind intercorelarea mecanismelor de producere a leziunilor întâlnite în parodontita cronică și tiroidita cronică autoimună, rezultatele obţinute rămân dificil de sistematizat, confirmând necesitatea abordării pluridisciplinare şi indivizualizate a fiecărui pacient.

Datele clinice, care inspiră investigaţiile, constată în mod cert asocierea parodontitei cronice cu tiroidita cronică autoimună, impunând studii populaţionale extinse în acest sens.

A systemic review. Nigerian Journal of Clinical Practice. 2011;14(3):253-61.

14. Mathis D, Benoist $C$. Microbiota and autoimmune disease: the hosted self. Cell Host Microbe. 2011 Oct 20;10(4):297-301.

15. Armitage GC. Periodontal diagnoses and classification of periodontal diseases. Periodontology 2000. 2004 Feb;34(1):9-21.

16. Tonetti MS, Greenwell H, Kornman KS. Staging and grading of periodontitis: Framework and proposal of a new classification and case definition. J Periodontol. 2018 Jun;89 Suppl 1:S159-S172.

17. Cardoso EM, Reis C, Manzanares-Céspedes MC. Chronic periodontitis, inflammatory cytokines, and interrelationship with other chronic diseases. Postgrad Med. 2018 Jan;130(1):98-104.

18. Borilova Linhartova P, Danek Z, Deissova T, Hromcik F, et al. Interleukin Gene Variability and Periodontal Bacteria in Patients with Generalized Aggressive Form of Periodontitis. Int J Mol Sci. 2020 Jul 2;21(13):4728

19. Ebersole JL, Graves CL, Gonzalez OA, et al. Aging, inflammation, immunity and periodontal disease. Periodontology 2000. 2016 Oct; 72(1):54-75.

20. Lertpimonchai A, Rattanasiri S, Arj-Ong Vallibhakara S, Attia J, Thakkinstian $A$. The association between oral hygiene and periodontitis: a systematic review and meta-analysis. Int Dent J. 2017 Dec;67(6):332-343.

21. Suárez LJ, Garzón H, Arboleda S, et al. Oral dysbiosis and autoimmunity: from local periodontal responses to an imbalanced systemic immunity. A review. Frontiers in Immunology. 2020;11:1664.

22. Morawska K, Maciejczyk M, Popławski $Ł$, et al. Enhanced salivary and general oxidative stress in Hashimoto's thyroiditis women in euthyreosis. Journal of Clinical Medicine. 2020 Jul;9(7):2102.

23. Pan $W$, Wang $Q$, Chen $Q$. The cytokine network involved in the host immune response to periodontitis. Int J Oral Sci. 2019 Nov 5;11(3):30

24. Dong T, Zhao F, Yuan K, et al. Association Between Serum Thyroid-Stimulating Hormone Levels and Salivary Microbiome Shifts. Front Cell Infect Microbiol. 2021;11:603291. 